\title{
AIM analysis, synthetic, kinetic and mechanistic investigations of the reaction between triphenylphosphine and dialkyl acetylenedicarboxylate in the presence of 3-methoxythiophenol
}

\author{
SAYYED MOSTAFA HABIBI KHORASSANI ${ }^{\mathrm{a}, *}$, MALEK TAHER MAGHSOODLOU ${ }^{\mathrm{a}}$, \\ HOJJAT GHASEMPOUR ${ }^{\mathrm{b}}$, MOHAMMAD ZAKARIANEZHAD ${ }^{\mathrm{c}}$, \\ MAHMOUD NASSIRI $^{\mathrm{d}}$ and ZAHRA GHAHGHAIE \\ ${ }^{a}$ Department of Chemistry, The University of Sistan and Baluchestan, 98135-674, Zahedan, Iran \\ ${ }^{b}$ Department of Chemistry, Kerman Branch, Islamic Azad University, 76351-31167, Kerman, Iran \\ ${ }^{c}$ Department of Chemistry, Payam Noor University, 19395-3697, Tehran, Iran \\ ${ }^{\mathrm{d}}$ Department of Maritime, The University of Chabahar, 99717-56499, Chabahar, Iran \\ e-mail: habibi_khorassani@yahoo.com
}

MS received 7 March 2012; revised 26 May 2012; accepted 15 June 2012

\begin{abstract}
Triphenylphosphine reacts with dialkyl acetylenedicarboxylates in the presence of 3methoxythiophenol to generate stable phosphorus ylides. These stable ylides exist in solution as a mixture of two geometrical isomers as a result of restricted rotation around the carbon-carbon partial double bond resulting from conjugation of the ylide moiety with the adjacent carbonyl group. Quantum mechanical calculations were employed to check the stability of the two geometrical isomers in phosphorous ylide by natural population analysis (NPA), atoms in molecules (AIM) methods and CHelpG keyword. To determine the kinetic parameters and mechanistic investigation of the reaction, they were monitored by UV spectrophotometry. The second order fits were automatically drawn, and the value of the second order rate constants $\left(k_{2}\right)$ were automatically calculated using standard equations. At the temperature range studied, the dependence of the second order rate constant $\left(\ln k_{2}\right)$ on reciprocal temperature was in good agreement with the Arrhenius equation. This provided the relevant plots to calculate the activation energy of all the reactions. Furthermore, useful information was obtained from studies of the effect of solvent, structure of reactions (different alkyl groups within the dialkyl acetylenedicarboxylates), and also concentration of reactants on the rate of reaction. The proposed mechanism was confirmed according to the obtained experimental results, and a steady state approximation. The first $\left(k_{2}\right)$ and third $\left(k_{3}\right)$ steps of the reactions were recognized as the rate determining and fast steps, respectively on the basis of experimental data. Also, the activation parameters involving $\Delta \mathrm{G}^{\#}, \Delta \mathrm{S}^{\#}$ and $\Delta \mathrm{H}^{\#}$ were obtained for all the reactions.
\end{abstract}

Keywords. Kinetic study; UV spectrophotometry; geometrical isomers; stable phosphorus ylides.

\section{Introduction}

Trivalent phosphorus compound is known to be a nucleophile, whereas it behaves as an electron donor toward good electron acceptor either in the ground or excited state. ${ }^{1,2}$ In recent years there has been increasing interest in the synthesis of organophosphorus compounds, that is, those bearing a carbon atom bonds directly to a phosphorus atom. ${ }^{3-19}$ This interest has resulted from the recognition of the value of such compounds in variety of biological, industrial and chemical synthetic uses. ${ }^{3-7}$ A large number of methods have appeared describing novel synthesis of organophosphorus compounds. ${ }^{6,7}$ There are many studies on the reaction between trivalent phosphorus nucleophiles and $\alpha, \beta$-unsaturated carbonyl

\footnotetext{
*For correspondence
}

compounds in the presence of a proton source such as alcohol or phenol. ${ }^{7}$ As part of our current studies on the development of new routes in stable phosphorus ylides synthesis, ${ }^{16-19}$ we now describe the reaction between triphenyl- phosphine $\mathbf{1}$ and dialkyl acetylenedicarboxylate esters $\mathbf{2}$ in the presence of 3-methoxythiophenol 3 which leads to the corresponding stable phosphorus ylids $\mathbf{4}$ in fairly high yield. These ylides usually exist as a mixture of the two geometrical isomers, although some ylides exhibit one geometrical isomer. Assignment of the stability of the two $Z$ - and $E$ - isomers is possible in phosphorus ylides by experimental methods such as ${ }^{1} \mathrm{H},{ }^{13} \mathrm{C}$ NMR and IR spectroscopy, mass spectrometry and elemental analysis. For this reason, quantum mechanical calculation has been performed in comparison with experimental data in order to gain a better understanding of the most important geometrical 
parameters and also relative energies of both the geometrical isomers.

\section{Experimental}

\subsection{Material, methods and apparatuses used}

Melting points and IR, UV spectra of all compounds were measured on an Electro thermal 9100 apparatus, a Shimadzu IR-460 spectrophotometer and a Cary UV/Vis spectrophotometer model Bio-300 with a $10 \mathrm{~mm}$ light-path black quartz spectrophotometer cell throughout the current work, respectively. The ${ }^{1} \mathrm{H},{ }^{13} \mathrm{C}$, and ${ }^{31} \mathrm{P}$ NMR spectra were obtained on a BRUKER DRX-300 AVANCE instrument in $\mathrm{CDCl}_{3}$ as solvent at $300.1,121.5$ and $75.5 \mathrm{MHz}$, respectively. The mass spectra were recorded with a GCMS-QP5050A mass spectrophotometer operating at an ionization potential of $70 \mathrm{eV}$. Elemental analysis for $\mathrm{C}, \mathrm{H}$ and $\mathrm{N}$ were performed using a Heraeus CHN-O-Rapid analyzer. 3-Methoxythiophenol, dialkyl acetylenedicarboxylates and triphenylphosphine, were purchased from Fluka, and used without further purification. All extra pure solvents including 1, 2-dichloroethane and ethyl acetate also obtained from Merk (Darmstadt, Germany). Quantum mechanical calculations were performed using Gaussian98 program and AIM2000 program packages.

\subsection{Synthesis of the ylide 4: General procedures}

To a magnetically stirred solution of triphenylphosphine $(0.26 \mathrm{~g}$ or $1 \mathrm{mmol})$ and 3 -methoxythiophenol in $10 \mathrm{~mL}$ of diethyl ether was added drop-wise a mixture of dimethyl acetylenedicarboxylate $(0.14 \mathrm{~g}$ or $1 \mathrm{mmol})$ in $3 \mathrm{~mL}$ of diethyl ether at $-5^{\circ} \mathrm{C}$ over $10 \mathrm{~min}$. After a few minutes stirring at room temperature the product was filtered, washed with cold diethyl ether $(3 \times 5 \mathrm{~mL})$ and was finally obtained as a cream powder, $0.52 \mathrm{~g}$, yield $96 \%$, m.p $159-161^{\circ} \mathrm{C}$, IR $(\mathrm{KBr})\left(v_{\max }, \mathrm{cm}^{-1}\right)$ : 1725 and $1630(2 \mathrm{C}=\mathrm{O})$. MS (m/z, \%): $544\left(\mathrm{M}^{+}, 3\right)$, $262\left(\mathrm{PPh}_{3}, 100\right), 183\left(\mathrm{PPh}_{2}, 91\right), 164\left(\mathrm{M}-\mathrm{PPh}_{3}\right.$ and $\left.2 \mathrm{CO}_{2} \mathrm{Me}, 18\right), 108$ (PPh, 39), 77 (Ph, 16). Anal. Calcd. For $\mathrm{C}_{31} \mathrm{H}_{29} \mathrm{O}_{5} \mathrm{PS}$ (544.23): C, 68.35; H, 5.37\% Found: $\mathrm{C}, 68.41 ; \mathrm{H}, 5.31 \%$.

2.2a Dimethyl-2-(3-methoxythiophenol-s-yl)-3(triphenylphosphanylidene)-butanedioate (4a): Major isomer: Z-4a (54\%): ${ }^{1} \mathrm{H}$ NMR $(300.1 \mathrm{MHz}$, $\left.\mathrm{CDCl}_{3}\right): \delta 3.11$ and $3.66\left(9 \mathrm{H}, 2 \mathrm{~s}, 3 \mathrm{OCH}_{3}\right), 4.12(1 \mathrm{H}$, $\left.\mathrm{d},{ }^{3} J_{\mathrm{PH}}=19.0 \mathrm{~Hz}, \mathrm{P}=\mathrm{C}-\mathrm{CH}\right), 6.55-7.67\left(19 \mathrm{H}_{\text {arom }}\right.$, $\mathrm{m}, 3 \mathrm{C}_{6} \mathrm{H}_{5}$ and $\left.\mathrm{C}_{6} \mathrm{H}_{4} \mathrm{~S}\right) .{ }^{13} \mathrm{C} \mathrm{NMR}\left(75.5 \mathrm{MHz}, \mathrm{CDCl}_{3}\right)$ : $\delta 41.92\left(\mathrm{~d},{ }^{1} J_{\mathrm{PC}}=127.1 \mathrm{~Hz}, \mathrm{P}=C\right), 49.15$ and $52.63\left(2 \mathrm{~s}, 2 \mathrm{OCH}_{3}\right), 53.81\left(\mathrm{~d},{ }^{2} J_{\mathrm{PC}}=12.9 \mathrm{~Hz}, \mathrm{P}=\mathrm{C}-\right.$ $\mathrm{CH}), \quad 55.17\left(\mathrm{OCH}_{3}\right), 112.36,116.35$ and 123.58 $\left(3 \mathrm{C}, \mathrm{C}_{6} \mathrm{H}_{4} \mathrm{~S}\right), 126.05\left(\mathrm{~d},{ }^{1} J_{\mathrm{PC}}=92.2 \mathrm{~Hz}, \mathrm{C}_{\mathrm{ipso}}\right)$, $128.54\left(\mathrm{~d},{ }^{3} J_{\mathrm{PC}}=11.8 \mathrm{~Hz}, \mathrm{C}_{\text {meta }}\right), 129.06(1 \mathrm{C}$, $\left.\mathrm{C}_{6} \mathrm{H}_{4} \mathrm{~S}\right), 131.99\left(\mathrm{~d},{ }^{4} J_{\mathrm{PC}}=2.7 \mathrm{~Hz}, \mathrm{C}_{\mathrm{para}}\right), 133.79(\mathrm{~d}$, $\left.{ }^{2} J_{\mathrm{PC}}=9.9 \mathrm{~Hz}, \mathrm{C}_{\text {ortho }}\right), 138.26$ and $159.27\left(2 \mathrm{C}, \mathrm{C}_{6} \mathrm{H}_{4} \mathrm{~S}\right)$, $169.21\left(\mathrm{~d},{ }^{3} J_{\mathrm{PC}}=12.4 \mathrm{~Hz}, \mathrm{C}=\mathrm{O}\right.$ ester $), 173.03(\mathrm{~d}$, $\left.{ }^{2} J_{\mathrm{PC}}=13.1 \mathrm{~Hz}, \mathrm{P}-\mathrm{C}=C\right) .{ }^{31} \mathrm{P}$ NMR $(121.5 \mathrm{MHz}$, $\left.\mathrm{CDCl}_{3}\right): \delta 22.18\left(\mathrm{Ph}_{3} \mathrm{P}^{+}-\mathrm{C}\right)$.

Minor isomer: E-4a (46\%): ${ }^{1} \mathrm{H}$ NMR $(300.1 \mathrm{MHz}$, $\left.\mathrm{CDCl}_{3}\right): \delta 3.58$ and $3.66\left(9 \mathrm{H}, 2 \mathrm{~s}, 3 \mathrm{OCH}_{3}\right), 4.27(1 \mathrm{H}$, $\left.\mathrm{d},{ }^{3} J_{\mathrm{PH}}=18.3 \mathrm{~Hz}, \mathrm{P}=\mathrm{C}-\mathrm{C} H\right), 6.55-7.67\left(19 \mathrm{H}_{\text {arom }}, \mathrm{m}\right.$, $3 \mathrm{C}_{6} \mathrm{H}_{5}$ and $\left.\mathrm{C}_{6} \mathrm{H}_{4} \mathrm{~S}\right) .{ }^{13} \mathrm{C}$ NMR $\left(75.5 \mathrm{MHz}, \mathrm{CDCl}_{3}\right): \delta$ $43.09\left(\mathrm{~d},{ }^{1} J_{\mathrm{PC}}=136.4 \mathrm{~Hz}, \mathrm{P}=C\right), 50.42$ and 52.63 $\left(2 \mathrm{~s}, 2 \mathrm{OCH}_{3}\right), 54.16\left(\mathrm{~d},{ }^{2} J_{\mathrm{PC}}=13.4 \mathrm{~Hz}, \mathrm{P}=\mathrm{C}-\mathrm{CH}\right)$, $55.17\left(\mathrm{OCH}_{3}\right), 112.53,116.51$ and $123.93\left(3 \mathrm{C}, \mathrm{C}_{6} \mathrm{H}_{4} \mathrm{~S}\right)$, $126.70\left(\mathrm{~d},{ }^{1} J_{\mathrm{PC}}=92.1 \mathrm{~Hz}, \mathrm{C}_{\mathrm{ipso}}\right), 128.70\left(\mathrm{~d},{ }^{3} J_{\mathrm{PC}}=\right.$ $\left.11.9 \mathrm{~Hz}, \mathrm{C}_{\text {meta }}\right), 129.06\left(1 \mathrm{C}, \mathrm{C}_{6} \mathrm{H}_{4} \mathrm{~S}\right), 131.99\left(\mathrm{~d},{ }^{4} J_{\mathrm{PC}}=\right.$ $\left.2.7 \mathrm{~Hz}, \mathrm{C}_{\text {para }}\right), 133.79$ (d, $\left.{ }^{2} J_{\mathrm{PC}}=9.9 \mathrm{~Hz}, \mathrm{C}_{\text {ortho }}\right), 138.29$ and $159.27\left(2 \mathrm{C}, \mathrm{C}_{6} \mathrm{H}_{4} \mathrm{~S}\right), 170.32\left(\mathrm{~d},{ }^{3} J_{\mathrm{PC}}=17.9 \mathrm{~Hz}\right.$, $\mathrm{C}=\mathrm{O}$ ester $), 172.23\left(\mathrm{~d},{ }^{2} J_{\mathrm{PC}}=14.2 \mathrm{~Hz}, \mathrm{P}-\mathrm{C}=C\right) .{ }^{31} \mathrm{P}$ NMR (121.5 MHz, $\left.\mathrm{CDCl}_{3}\right): \delta 22.57\left(\mathrm{Ph}_{3} \mathrm{P}^{+}-\mathrm{C}\right)$.

2.2b Diethyl-2-(3-methoxythiophenol-s-yl)-3(triphenylphosphanylidene)-butanedioate (4b): White powder, $0.54 \mathrm{~g}$, yield $94 \%$, m.p $140-142^{\circ} \mathrm{C}$, IR (KBr) $\left(v_{\max }, \mathrm{cm}^{-1}\right): 1730$ and $1658(2 \mathrm{C}=\mathrm{O}) . \mathrm{MS}(\mathrm{m} / \mathrm{z}, \%)$ : 466 (M- $\left.\mathrm{C}_{7} \mathrm{H}_{7} \mathrm{O}, 34\right), 434$ (M-PPh and Et, 14), 360 (M$\mathrm{PPh}_{2}$ and Et, 5), $262\left(\mathrm{PPh}_{3}, 69\right), 183\left(\mathrm{PPh}_{2}, 33\right), 108$ (PPh, 21), 77 (Ph, 90). Anal. Calcd. For $\mathrm{C}_{33} \mathrm{H}_{33} \mathrm{O}_{5} \mathrm{PS}$ (572.26): C, 69.20; H, 5.81\% Found: C, 69.27; H, $5.87 \%$.

Major isomer: Z-4b (63\%): ${ }^{1} \mathrm{H}$ NMR $(300.1 \mathrm{~Hz}$, $\left.\mathrm{CDCl}_{3}\right) \delta 0.41$ and $1.18\left(6 \mathrm{H}, 2 \mathrm{t},{ }^{3} J_{\mathrm{HH}}=7.0 \mathrm{~Hz}\right.$, $\left.2 \mathrm{OCH}_{2} \mathrm{CH}_{3}\right), 3.64\left(3 \mathrm{H}, \mathrm{s}, \mathrm{OCH}_{3}\right), 3.68$ and 4.10 (4 $\mathrm{H}, 2 \mathrm{~m}, 2 \mathrm{ABX}_{3}$ system, $\left.2 \mathrm{OCH}_{2} \mathrm{CH}_{3}\right), 4.32(1 \mathrm{H}, \mathrm{d}$, $\left.{ }^{3} J_{\mathrm{PH}}=18.8 \mathrm{~Hz}, \mathrm{P}=\mathrm{C}-\mathrm{CH}\right), 6.58-7.67\left(19 \mathrm{H}_{\text {arom }}, \mathrm{m}\right.$, $3 \mathrm{C}_{6} \mathrm{H}_{5}$ and $\left.\mathrm{C}_{6} \mathrm{H}_{4} \mathrm{~S}\right) .{ }^{13} \mathrm{C}$ NMR $\left(75.5 \mathrm{MHz}, \mathrm{CDCl}_{3}\right): \delta$ 14.06 and $14.23\left(2 \mathrm{~s}, 2 \mathrm{OCH}_{2} \mathrm{CH}_{3}\right), 41.65\left(\mathrm{~d},{ }^{1} J_{\mathrm{PC}}=\right.$ $126.8 \mathrm{~Hz}, \mathrm{P}=C), 54.24\left(\mathrm{~d},{ }^{2} J_{\mathrm{PC}}=15.5 \mathrm{~Hz}, \mathrm{P}=\mathrm{C}-\right.$ $\mathrm{CH}), 55.30$ and $55.61\left(2 \mathrm{~s}, 2 \mathrm{OCH}_{2} \mathrm{CH}_{3}\right), 60.98\left(\mathrm{OCH}_{3}\right)$, $112.41,116.52$ and $123.95\left(3 \mathrm{C}, \mathrm{C}_{6} \mathrm{H}_{4} \mathrm{~S}\right), 126.90(\mathrm{~d}$, $\left.{ }^{1} J_{\mathrm{PC}}=92.2 \mathrm{~Hz}, \mathrm{C}_{\mathrm{ipso}}\right), 128.74\left(\mathrm{~d},{ }^{3} J_{\mathrm{PC}}=12.8 \mathrm{~Hz}\right.$, $\left.\mathrm{C}_{\text {meta }}\right), 129.50\left(1 \mathrm{C}, \mathrm{C}_{6} \mathrm{H}_{4} \mathrm{~S}\right), 131.77\left(\mathrm{C}_{\text {para }}\right), 133.62$ (d, $\left.{ }^{2} J_{\mathrm{PC}}=9.9 \mathrm{~Hz}, \mathrm{C}_{\text {ortho }}\right), 135.09$ and $159.27\left(2 \mathrm{C}, \mathrm{C}_{6} \mathrm{H}_{4} \mathrm{~S}\right)$, $168.70\left(\mathrm{~d},{ }^{3} J_{\mathrm{PC}}=12.8 \mathrm{~Hz}, \mathrm{C}=\mathrm{O}\right), 172.31\left(\mathrm{~d},{ }^{2} J_{\mathrm{PC}}=\right.$ $8.5 \mathrm{~Hz}, \mathrm{P}-\mathrm{C}=C) .{ }^{31} \mathrm{P}$ NMR $\left(121.5 \mathrm{MHz}, \mathrm{CDCl}_{3}\right): \delta$ $22.12\left(\mathrm{Ph}_{3} \mathrm{P}^{+}-\mathrm{C}\right)$.

Minor isomer: E-4b (37\%): ${ }^{1} \mathrm{H}$ NMR $(300.1 \mathrm{MHz}$, $\left.\mathrm{CDCl}_{3}\right): \delta 1.25$ and $1.30\left(6 \mathrm{H} .2 \mathrm{t} .{ }^{3} J_{\mathrm{HH}}=7.0\right.$, $\left.2 \mathrm{OCH}_{2} \mathrm{CH}_{3}\right), 3.64\left(3 \mathrm{H}, \mathrm{s}, \mathrm{OCH}_{3}\right), 3.68$ and $4.10(4 \mathrm{H}$, 
$2 \mathrm{~m}, 2 \mathrm{ABX}_{3}$ system, $\left.2 \mathrm{OCH}_{2} \mathrm{CH}_{3}\right), 4.32\left(1 \mathrm{H}, \mathrm{d},{ }^{3} J_{\mathrm{PH}}=\right.$ $18.8 \mathrm{~Hz}, \mathrm{P}=\mathrm{C}-\mathrm{CH}), 6.58-7.67\left(19 \mathrm{H}_{\text {arom }}, \mathrm{m}, 3 \mathrm{C}_{6} \mathrm{H}_{5}\right.$ and $\left.\mathrm{C}_{6} \mathrm{H}_{4} \mathrm{~S}\right) .{ }^{13} \mathrm{C}$ NMR $\left(75.5 \mathrm{MHz}, \mathrm{CDCl}_{3}\right): \delta 13.55$ and $13.83\left(2 \mathrm{OCH}_{2} \mathrm{CH}_{3}\right), 43.39\left(\mathrm{~d},{ }^{1} J_{\mathrm{PC}}=135.6 \mathrm{~Hz}\right.$, $\mathrm{P}=C), 54.61\left(\mathrm{~d},{ }^{2} J_{\mathrm{PC}}=15.2 \mathrm{~Hz}, \mathrm{P}=\mathrm{C}-C \mathrm{H}\right), 55.61$ and $57.61\left(2 \mathrm{OCH}_{2} \mathrm{CH}_{3}\right), 60.98\left(\mathrm{OCH}_{3}\right), 112.23,116.52$ and $123.81\left(3 \mathrm{C}, \mathrm{C}_{6} \mathrm{H}_{4} \mathrm{~S}\right), 126.27\left(\mathrm{~d},{ }^{1} J_{\mathrm{PC}}=92.1 \mathrm{~Hz}, \mathrm{C}_{\mathrm{ipso}}\right)$, $128.78\left(\mathrm{~d},{ }^{3} J_{\mathrm{PC}}=12.7 \mathrm{~Hz}, \mathrm{C}_{\text {meta }}\right), 129.54\left(1 \mathrm{C}, \mathrm{C}_{6} \mathrm{H}_{4} \mathrm{~S}\right)$, $131.49\left(\mathrm{C}_{\mathrm{para}}\right), 133.75\left(\mathrm{~d},{ }^{2} J_{\mathrm{PC}}=9.9 \mathrm{~Hz}, \mathrm{C}_{\text {ortho }}\right), 135.13$ and $159.27\left(2 \mathrm{C}, \mathrm{C}_{6} \mathrm{H}_{4} \mathrm{~S}\right), 169.98\left(\mathrm{~d},{ }^{3} J_{\mathrm{PC}}=17.9 \mathrm{~Hz}\right.$, $\mathrm{C}=\mathrm{O}), 172.59\left(\mathrm{~d},{ }^{2} J_{\mathrm{PC}}=8.9 \mathrm{~Hz}, \mathrm{P}-\mathrm{C}=C\right),{ }^{31} \mathrm{P}$ NMR $\left(121.5 \mathrm{MHz}, \mathrm{CDCl}_{3}\right): \delta 22.52\left(\mathrm{Ph}_{3} \mathrm{P}^{+}-\mathrm{C}\right)$.

\subsection{Calculation}

For assignment of the two $Z$ - and $E$-isomer as a minor or major form of phosphorus ylides $\mathbf{4 a}-\mathbf{b}$ containing a 3-methoxythiophenol, first the $Z$ - and the $E$ - isomer were optimized for all ylide structures at $\mathrm{HF} / 6$ $31 \mathrm{G}(\mathrm{d}, \mathrm{p})$ level of theory ${ }^{20}$ by Gaussian98 package program. ${ }^{21}$ The relative stabilization energies in both the geometrical isomer have been calculated at HF/6$31 \mathrm{G}(\mathrm{d}, \mathrm{p})$ and B3LYP/6-311++ $\mathrm{G}^{* *}$ levels. Atoms in molecules (AIM), ${ }^{22}$ natural population analysis (NPA) methods and CHelpG keyword at HF/6-31G(d,p) level of theory have been employed in order to gain a better understanding of most geometrical parameters of both the $E-4(a, b)$ and the $Z-4(a, b)$ of phosphorus ylides. The numbers of critical points and intramolecular hydrogen bonds as well as the charge of atoms that constructed on the two $Z$ - and $E$-isomer have been recognized. The results altogether reveal the effective factors on stability of the two $Z$ - and $E$-geometrical isomers. The relative stabilization energies for the two $[Z-4(\mathbf{a}, \mathbf{b})$ and $E-\mathbf{4}(\mathbf{a}, \mathbf{b})]$ isomers (see figures 1 and 2$)$ are reported in table 1 , as can be seen, $E-\mathbf{4 a}$ and $E \mathbf{- 4 b}$ isomers are more stable than $Z-\mathbf{4 a}$ and $Z$-4b forms (1.38 and $2.10 \mathrm{kcal} / \mathrm{mol}$, respectively) at B3LYP level.
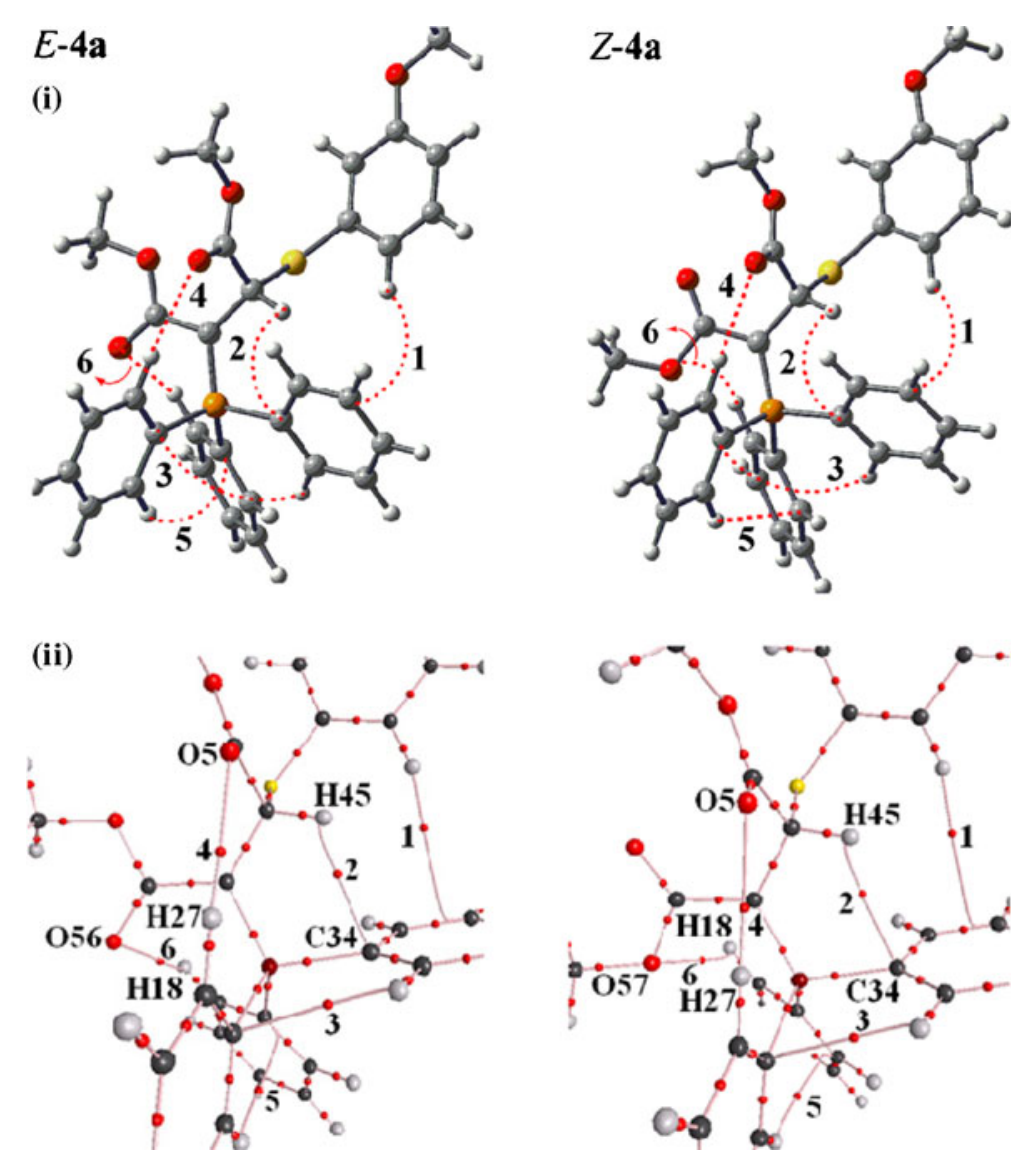

Figure 1. (i) Intramolecular hydrogen bonds (dotted lines) in the two $E$-4a and Z-4a geometrical isomers of stable ylide 4a, (ii) Part of molecular graphs, including intramolecular hydrogen bond critical points (BCPS) for the two rotational isomers such as $E-\mathbf{4 a}$ and $Z$ 4a. Small red spheres, and lines corresponding to BCPS bond paths, respectively. 

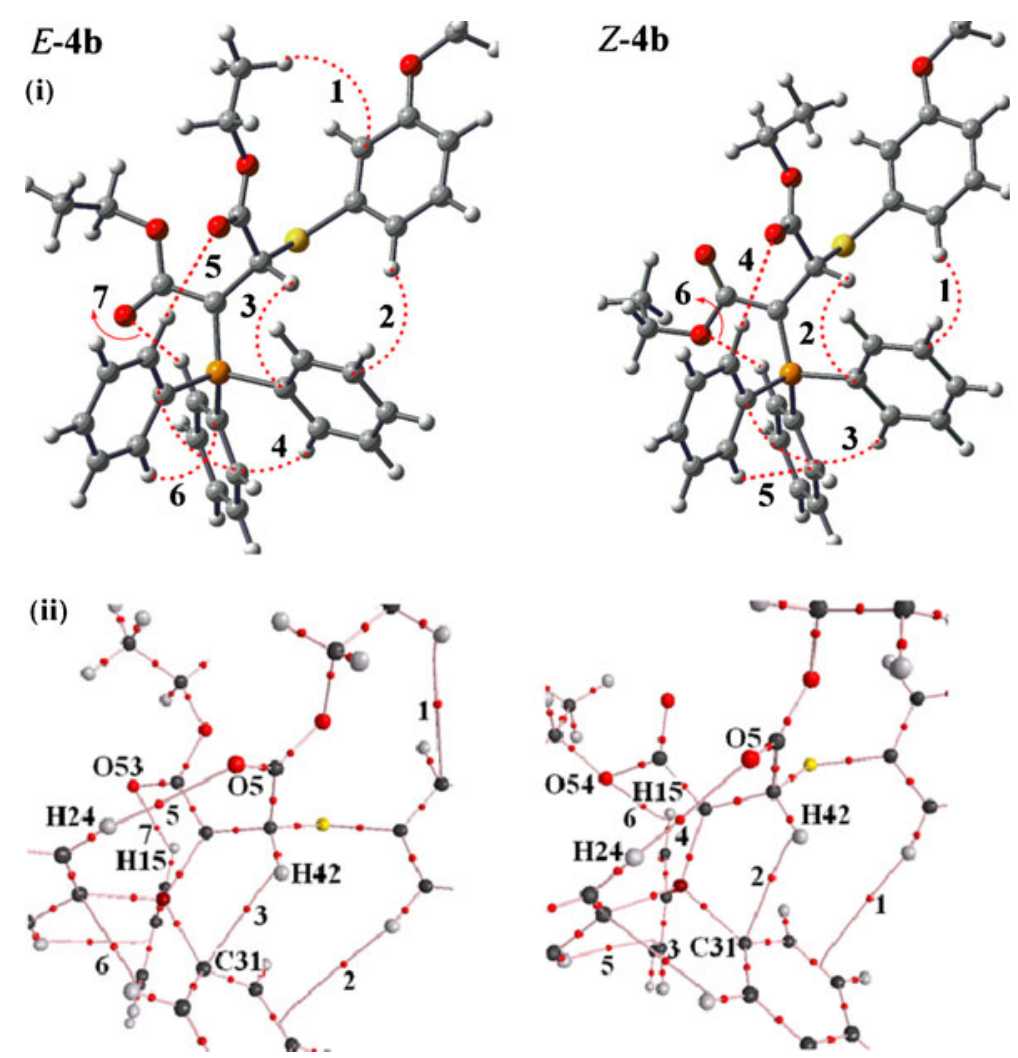

Figure 2. (i) Intramolecular hydrogen bonds (dotted lines) in the two $E-\mathbf{4 b}$ and $Z-\mathbf{4 b}$ geometrical isomers of stable ylide $\mathbf{4 b}$, (ii) Part of molecular graphs, including intramolecular hydrogen bond critical points (BCPS) for the two rotational isomers such as $E \mathbf{- 4 b}$ and $Z$ 4b. Small red spheres, and lines corresponding to BCPS bond paths, respectively.

Further investigation was undertaken in order to determine more effective factors on stability of the two $Z$ - and $E$-isomer on the basis of AIM calculations at $\mathrm{HF} / 6-31 \mathrm{G}(\mathrm{d}, \mathrm{p})$ level of theory by the AIM2000 program package. ${ }^{23}$ In recent years, AIM theory has often applied in the analysis of $\mathrm{H}$-bonds. In this theory, the topological properties of the electron density distribution are derived from the gradient vector field of the electron density $\nabla \rho(\mathrm{r})$ and from the Laplacian of the electron density $\nabla^{2} \rho(\mathrm{r})$. The Laplacian of the electron density, $\nabla^{2} \rho(r)$, identifies regions of space wherein the electronic charge is locally depleted $\left[\nabla^{2} \rho(r)>0\right]$ or

Table 1. The relative energy $(\mathrm{kcal} / \mathrm{mol})$ for both the $Z$ - and $E$-isomer of ylides $\mathbf{4 a}$ and $\mathbf{4 b}$, obtained at HF/6-31G(d,p) and B3LYP/6-311++G(d,p) levels.

\begin{tabular}{lcc}
\hline Geometrical isomer & HF & B3LYP \\
\hline$Z-4 a$ & 1.37 & 1.38 \\
$E-\mathbf{4 a}$ & 0.00 & 0.00 \\
$Z-\mathbf{4 b}$ & 2.00 & 2.10 \\
$E-\mathbf{4 b}$ & 0.00 & 0.00 \\
\hline
\end{tabular}

built up $\left[\nabla^{2} \rho(r)<0\right] .{ }^{22}$ Two interacting atoms in a molecule form a critical point in the electron density, where $\nabla \rho(\mathrm{r})=0$, called the bond critical point (BCP). The values of the charge density and its Laplacian at these critical points give useful information regarding the strength of the H-bonds. ${ }^{23}$ The ranges of $\rho(\mathrm{r})$ and $\nabla^{2} \rho(\mathrm{r})$ are $0.002-0.035 \mathrm{e} / \mathrm{a}_{0}^{3}$ and $0.024-0.139 \mathrm{e} / \mathrm{a}_{0}^{5}$, respectively, if $\mathrm{H}$-bonds exist. ${ }^{24}$ The AIM calculation indicates intramolecular hydrogen bond critical points (H-BCP) for the two $Z-\mathbf{4}(\mathbf{a}, \mathbf{b})$ and $E-\mathbf{4}(\mathbf{a}, \mathbf{b})$ isomers. Intramolecular H-BCPs along with a part of molecular graphs for the two rotational isomers are shown in figures 1 and 2 (dotted line). Most important geometrical parameters involving some $\mathrm{H}$-bonds (bond length and their relevant bond angle) are reported in table 2 . The electron density $\rho(\mathrm{r}) \times 10^{3}$, Laplacian of electron density $\nabla^{2} \rho(\mathrm{r}) \times 10^{3}$, and energy density $-\mathrm{H}(\mathrm{r}) \times$ $10^{4}$ are also reported in tables 3 and 4 . A negative total energy density at the $\mathrm{BCP}$ reflects a dominance of potential energy density, which is the consequence of accumulated stabilizing electronic charge. ${ }^{25}$ Here, the number of hydrogen bonds in both categories $(E-\mathbf{4 a}$ and $Z-4 \mathbf{a})$ and (E-4b and Z-4b) are (6 and 6) and also (7 
Table 2. Most important geometrical parameters corresponding to H-bonds (bond lengths and their relevant angles) for the two $Z$ and $E$ isomers in both ylides $\mathbf{4 a}$ and $\mathbf{4 b}$. Bond lengths in Angstroms and bond angles in degrees, respectively.

\begin{tabular}{llccc}
\hline \multicolumn{1}{c}{$E-\mathbf{4 a}$} & $Z-\mathbf{4 a}$ & $E-\mathbf{4 b}$ & $Z-\mathbf{b} \mathbf{b}$ \\
\hline $\mathrm{C}_{24} \mathrm{H}_{27} \ldots \mathrm{O}_{5}$ & $2.51^{\mathrm{a}}(170.9)^{\mathrm{b}}$ & $2.52(170.5)$ & & \\
$\mathrm{C}_{3} \mathrm{H}_{45} \ldots \mathrm{C}_{34}$ & $2.54(117.5)$ & $2.55(116.8)$ & & \\
$\mathrm{C}_{14} \mathrm{H}_{18} \ldots \mathrm{O}_{56(57)}{ }^{\mathrm{c}}$ & $2.36(125.3)$ & $2.55(115.0)$ & & \\
$\mathrm{C}_{21} \mathrm{H}_{24} \ldots \mathrm{O}_{5}$ & & $2.52(170.8)$ & $2.52(170.3)$ \\
$\mathrm{C}_{3} \mathrm{H}_{42} \ldots \mathrm{C}_{31}$ & & $2.54(117.8)$ & $2.55(117.0)$ \\
$\mathrm{C}_{11} \mathrm{H}_{15} \ldots \mathrm{O}_{53(54)}{ }^{\mathrm{d}}$ & & $2.57(114.2)$ & $2.55(117.0)$ \\
\hline a bond length & & & \\
b bond angle \\
c,d are relevant to the two $Z$-4a and $Z$-4b isomers, respectively
\end{tabular}

and 6), respectively. The values of $\rho \times 10^{3}$ and $\nabla^{2} \rho(\mathrm{r}) \times$ $10^{3}$ for those are in the ranges [(3.09-12.8 and 2.93$\left.11.3 \mathrm{e} / \mathrm{a}_{0}^{3}\right)$ and $\left(2.47-12.7\right.$ and $\left.\left.2.88-11.3 \mathrm{e} / \mathrm{a}_{0}^{3}\right)\right]$ and also [(9.38-41.7 and 8.94-42.0 $\left.\mathrm{e} / \mathrm{a}_{0}^{5}\right)$ and (8.08-47.1 and $\left.\left.8.79-41.9 \mathrm{e} / \mathrm{a}_{0}^{5}\right)\right]$, respectively. In addition, the Hamiltonian $\left[-\mathrm{H}(\mathrm{r}) \times 10^{4}\right]$ are in the ranges $[(5.26-17.4$ and 5.09-17.6 au) and (4.47-18.9 and 5.03-17.4 au)], respectively (tables 3 and 4 ). These HBs show $\nabla^{2} \rho(\mathrm{r})>$ 0 and $\mathrm{H}(\mathrm{r})<0$, which according to classification of Rozas et al. ${ }^{26}$ are medium-strength hydrogen bonds. In both ylides the dipole moment for the two $E-4 \mathbf{a}$ and $E-4 \mathbf{b}$ isomers (4.86 and 4.91 D) are smaller than the two $Z-4 \mathbf{a}$ and $Z-\mathbf{4 b}$ isomers $(6.58$ and $6.58 \mathrm{D}$, respectively) and the value of $-\mathrm{H}_{\text {tot }}\left(=\sum-\mathrm{H}(\mathrm{r}) \times 10^{4}\right)$ for the $E$-4a isomer (69.8 au) is smaller than the $Z$-4a isomer (73.2 au). Although, $-\mathrm{H}_{\text {tot }}$ in the $E-\mathbf{4 a}$ is smaller than the $Z-\mathbf{4 a}$ and appear as an effective factor on instability of the $E-\mathbf{4 a}$, but the values of dipole moment and relative stabilization energy in the $E$-4a are smaller than $Z-\mathbf{4 a}$ as two important facts on stability of $E-\mathbf{4 a}$. The values of dipole moment and relative stabilization energy in the $E-\mathbf{4 b}$ isomer are smaller than $Z-\mathbf{4 b}$ isomer as two important facts on stability of $E-\mathbf{4 b}$, and also for this categories ( $E-\mathbf{4 b}$ and $Z-\mathbf{4 b}$ isomers) the number of hydrogen bond ( 7 and 6 ) and the value of $-\mathrm{H}_{\text {tot }}(79.7$ and $73.1 \mathrm{au})$ in the $E-\mathbf{4 b}$ are larger than $Z$ $\mathbf{4 b}$ as two other main factors on stability of the $E-\mathbf{4} \mathbf{b}$. The results are summarized in table 5 . On the basis of theoretical calculations (table 1), both the E-4a and $E-4 b$ have a slight stability with respect to the two $Z$-4a and $Z$-4b $(1.38$ and $2.10 \mathrm{kcal} / \mathrm{mol}$, respectively) isomers seems to be in agreement with the results of predictable properties of the most important geometrical parameters (table 5). On the contrary, they are not compatible with the experimental results from the ${ }^{1} \mathrm{H},{ }^{13} \mathrm{C},{ }^{31} \mathrm{P}$ NMR spectroscopy which indicate the two isomers of $Z-\mathbf{4 a}$ and $Z-\mathbf{4 b}$ with the experimental abundance percentage of $54 \%$ and $63 \%$ (major forms)
Table 3. The values of $\mathrm{a}=\rho(\mathrm{r}) \times 10^{3}, \mathrm{~b}=\nabla^{2} \rho(\mathrm{r}) \times 10^{3}$ and $\mathrm{c}=-\mathrm{H}(\mathrm{r}) \times 10^{4}$ for both the $Z-\mathbf{4 a}$ and $E-\mathbf{4 a}$ isomers of ylide 4a calculated at the hydrogen bond critical points. All quantities are in atomic units.

\begin{tabular}{cccccccc}
\hline$E$ & $\mathrm{a}$ & $\mathrm{b}$ & $\mathrm{c}$ & $Z$ & $\mathrm{a}$ & $\mathrm{b}$ & $\mathrm{c}$ \\
\hline 1 & 3.09 & 9.38 & 5.26 & 1 & 2.93 & 8.94 & 5.09 \\
2 & 11.5 & 41.7 & 16.8 & 2 & 11.3 & 42.0 & 17.6 \\
3 & 9.52 & 36.0 & 17.4 & 3 & 9.32 & 34.9 & 16.9 \\
4 & 8.07 & 29.1 & 6.74 & 4 & 7.95 & 28.8 & 6.86 \\
5 & 9.04 & 31.5 & 14.9 & 5 & 9.25 & 31.9 & 14.3 \\
6 & 12.8 & 47.1 & 8.59 & 6 & 9.32 & 37.6 & 12.4 \\
\hline
\end{tabular}

Table 4. The values of $\mathrm{a}=\rho(\mathrm{r}) \times 10^{3}, \mathrm{~b}=\nabla^{2} \rho(\mathrm{r}) \times 10^{3}$ and $\mathrm{c}=-\mathrm{H}(\mathrm{r}) \times 10^{4}$ for both the $Z-\mathbf{4 b}$ and $E-\mathbf{4 b}$ isomers of ylide $\mathbf{4 b}$ calculated at the hydrogen bond critical points. All quantities are in atomic units.

\begin{tabular}{cccccccc}
\hline$E$ & $\mathrm{a}$ & $\mathrm{b}$ & $\mathrm{c}$ & $Z$ & $\mathrm{a}$ & $\mathrm{b}$ & $\mathrm{c}$ \\
\hline 1 & 2.47 & 8.08 & 4.47 & 1 & 2.88 & 8.79 & 5.03 \\
2 & 3.20 & 9.69 & 5.38 & 2 & 11.3 & 41.9 & 17.4 \\
3 & 11.5 & 41.7 & 16.8 & 3 & 9.32 & 34.6 & 16.8 \\
4 & 9.49 & 35.8 & 17.3 & 4 & 8.00 & 28.9 & 6.80 \\
5 & 7.99 & 28.9 & 6.8 & 5 & 9.27 & 32.1 & 14.4 \\
6 & 9.03 & 31.4 & 18.9 & 6 & 8.96 & 36.5 & 12.6 \\
7 & 12.7 & 47.1 & 9.96 & & & & \\
\hline
\end{tabular}

Table 5. The most important geometrical parameters involving the value of $-\mathrm{H}_{\mathrm{tot}} / \mathrm{au}$, dipole moment/D and the number of hydrogen bonds for the two $Z$ - and $E$-isomer of ylides $\mathbf{4 a}$ and $\mathbf{4 b}$.

\begin{tabular}{lccc}
\hline $\begin{array}{l}\text { Geometrical } \\
\text { isomer }\end{array}$ & $-\mathrm{H}_{\mathrm{tot}} / \mathrm{au}$ & $\begin{array}{c}\text { Dipole } \\
\text { moment/D }\end{array}$ & $\begin{array}{c}\text { Number of } \\
\text { hydrogen bond }\end{array}$ \\
\hline E-4a & 69.8 & 4.86 & 6 \\
$Z$-4a & 73.2 & 6.58 & 6 \\
E-4b & 79.7 & 4.91 & 7 \\
$Z$-4b & 73.1 & 6.58 & 6 \\
\hline
\end{tabular}


Table 6. The charges on different atoms for the two $Z$ and $E$-isomer in ylides $4 \mathbf{a}-\mathbf{b}$, calculated at $\mathrm{HF} / 6-31 \mathrm{G}(\mathrm{d}, \mathrm{p})$ theoretical level.

\begin{tabular}{|c|c|c|c|c|}
\hline Number of atom & $(E-\mathbf{4 a})$ & $(Z-4 a)$ & $(E-\mathbf{4 b})$ & $(Z-4 b)$ \\
\hline $\mathrm{C}_{1}$ & $1.87^{\mathrm{a}}(0.96)^{\mathrm{b}}(0.85)^{\mathrm{c}}$ & $1.86(0.96)(0.86)$ & $1.86(0.96)(0.85)$ & $1.87(0.96)(0.86)$ \\
\hline $\mathrm{C}_{2}$ & $-0.79(-0.88)(-0.50)$ & $-0.83(-0.89)(-0.43)$ & $-0.79(-0.88)(-0.48)$ & $-0.80(-0.89)(-0.46)$ \\
\hline $\mathrm{C}_{3}$ & $0.28(-0.44)(0.17)$ & $0.28(-0.43)(0.14)$ & $0.27(-0.44)(0.25)$ & $0.28(-0.43)(0.27)$ \\
\hline$P_{11(8)}^{d}$ & $3.25(1.88)(0.27)$ & $3.25(1.87)(0.21)$ & $3.25(1.88)(0.19)$ & $3.24(1.87)(0.21)$ \\
\hline $\mathrm{O}_{56(53)}$ & $-1.40(-0.80)(-0.70)$ & $-1.37(-0.76)(-0.64)$ & $-1.40(-0.80)(-0.68)$ & $-1.39(-0.76)(-0.63)$ \\
\hline $\mathrm{O}_{57(54)}$ & $-1.25(-0.64)(-0.36)$ & $-1.29(-0.66)(-0.47)$ & $-1.26(-0.65)(-0.46)$ & $-1.30(-0.67)(-0.53)$ \\
\hline
\end{tabular}

are slightly more stable isomer with respect to the $E$ 4(a, b) (minor forms). Perhaps, this different behaviour is relevant to the different media; employment of phase gas for theoretical calculation and liquid phase for experimental data.

Also, the charge on different atoms which are calculated by AIM and NPA methods and also CHelpG keyword at $\mathrm{HF} / 6-31 \mathrm{G}(\mathrm{d}, \mathrm{p})$ level are reported in table 6 for the two $Z$ - and $E$-isomers of ylides $\mathbf{4 a}$ and $\mathbf{4 b}$. There is a good agreement between the obtained results from two methods and CHelpG keyword.

\section{Kinetics studies}

To gain further insight into the reaction mechanism between triphenylphosphine 1, dialkyl acetylenedicarboxylates $\mathbf{2}$ (2a, $\mathbf{2 b}$ and $\mathbf{2 c}$ ) and 3-methoxythiophenol 3 (as a SH- compound) for generation of phosphorus ylids $4 \mathbf{a}-\mathbf{c}$, a kinetic study of the reactions was undertaken by UV spectrophotometric technique. First, it was

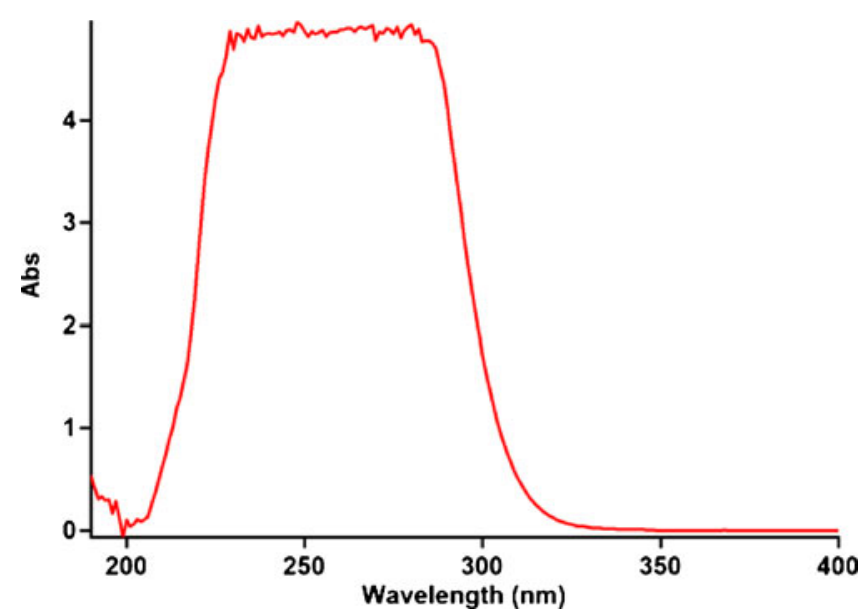

Figure 3. The UV spectrum of $10^{-3} \mathrm{M}$ triphenylphosphine 1 in 1, 2-dichloroethane. necessary to find the appropriate wavelength to follow the kinetic study of the reaction. For this purpose, in the first experiment, $3 \times 10^{-3} \mathrm{M}$ solution of compounds 1, 2c and 3 was prepared in 1, 2-dichloroethane as solvent. An approximately $3 \mathrm{~mL}$ aliquot from each reactant was pipetted into a $10 \mathrm{~mm}$ light path quartz spectrophotometer cell, and the relevant spectra were recorded over the wavelength range 190-400 nm. Figures 3, 4 and 5 show the ultraviolet spectra of compounds $1,2 \mathrm{c}$ and $\mathbf{3}$, respectively. In a second experiment, $1 \mathrm{~mL}$ aliquot from the $3 \times 10^{-3} \mathrm{M}$ solutions of each compound of $\mathbf{1}$ and $\mathbf{3}$ was pipetted first into a quartz spectrophotometer cell (as there is no reaction between them), later $1 \mathrm{~mL}$ aliquot of the $3 \times 10^{-3} \mathrm{M}$ solution of reactant $\mathbf{2 c}$ was added to the mixture and the reaction monitored by recording scans of the entire spectra every $7 \mathrm{~min}$ over the whole reaction time at ambient temperature. The ultra-violet spectra shown in figure 6 are typical. From this, the appropriate wavelength was found to be $330 \mathrm{~nm}$ (corresponding mainly to product 4). Since at this wavelength, compounds $\mathbf{1}$, $\mathbf{2 c}$ and $\mathbf{3}$ have relatively no absorbance value. This provided the opportunity to fully investigate the kinetics of

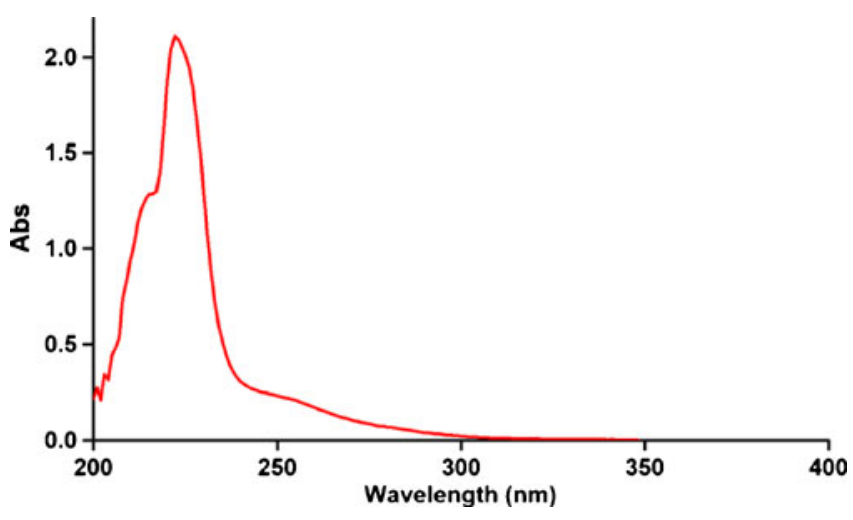

Figure 4. The UV spectrum of $10^{-3} \mathrm{M}$ di-tert-butyl acetylenedicarboxylate $\mathbf{2 c}$ in 1, 2-dichloroethane. 


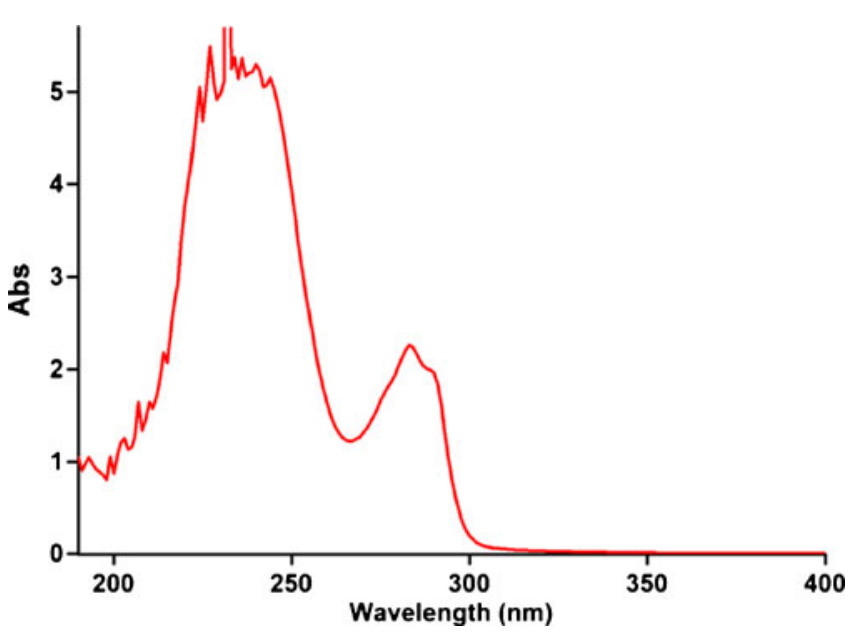

Figure 5. The UV spectrum of $10^{-3} \mathrm{M}$ 3-methoxythiophenol 3 in 1, 2-dichloroethane.

the reaction between triphenylphosphine 1 , di-tert-butyl acetylenedicarboxylate $\mathbf{2 c}$ and 3-methoxythiophenol $\mathbf{3}$ at $330 \mathrm{~nm}$ in the presence of 1,2-dichloroethaneas solvent. Since the spectrophotometer cell of the UV instrument had a $10 \mathrm{~mm}$ light-path cuvette, the UV-vis spectra of compound $\mathbf{4 c}$ were measured over the concentration range $\left(2 \times 10^{-4} \mathrm{M} \leq \mathrm{M}_{4 \mathrm{c}} \leq 10^{-3} \mathrm{M}\right)$ to check for a linear relationship between absorbance values and concentrations. With the suitable concentration range and wavelength identified, the following procedure was employed.

For each kinetic experiment, $1 \mathrm{~mL}$ aliquot from each freshly made $3 \times 10^{-3} \mathrm{M}$ solution of compounds $\mathbf{1}$ and 3 in 1,2-dichloroethane was pipetted into a quartz cell, and then a $1 \mathrm{~mL}$ aliquot of the $3 \times 10^{-3} \mathrm{M}$ of solution of reactant $\mathbf{2 c}$ was added to the mixture, keeping the temperature constant at $12.0^{\circ} \mathrm{C}$. The reaction kinetics

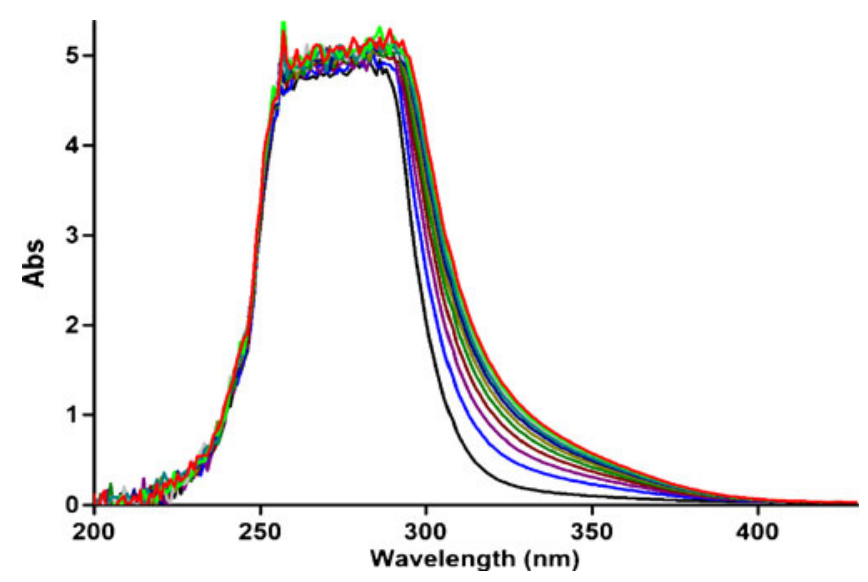

Figure 6. The UV spectra of the reaction between 1, 2c and 3 with $10^{-3} \mathrm{M}$ concentration of each compound as reaction proceeds in 1, 2-dichloroethane with $10 \mathrm{~mm}$ light-path cell for geometrical of ylide $\mathbf{4 c}$.

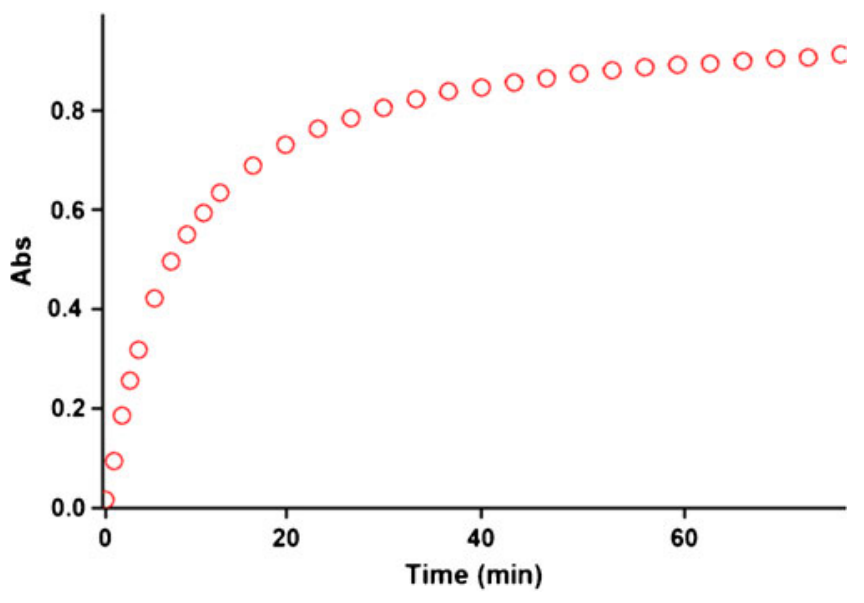

Figure 7. The experimental absorbance changes (dotted line) against time at $330 \mathrm{~nm}$ for the reaction between compounds $\mathbf{1}, \mathbf{2 c}$ and $\mathbf{3}$ at $12.0^{\circ} \mathrm{C}$ in 1,2 -dichloroethane.

was followed by plotting UV absorbance against time. Figure 7 shows the absorbance change (dotted line) versus time for the 1:1:1 addition reaction between compounds $\mathbf{1}, \mathbf{2 c}$ and $\mathbf{3}$ at $12.0^{\circ} \mathrm{C}$. The infinity absorbance $\left(\mathrm{A}_{\infty}\right)$ that is the absorbance at reaction completion, can be obtained from figure 7 at $\mathrm{t}=78 \mathrm{~min}$. With respect to this value, zero, first or second curve fitting could be drawn automatically for the reaction by the software ${ }^{27}$ associated with the UV instrument. Using the original experimental absorbance versus time data provided a second-order fit curve (full line) that fits exactly the experimental curve (dotted line) as shown in figure 8 . Thus, the reaction between triphenylphosphine $\mathbf{1}$, di-tert-butyl acetylenedicarboxylate $\mathbf{2 c}$ and $\mathbf{3}$ follows second-order kinetics. The second-order rate constant $\left(k_{2}\right)$ is then automatically calculated using a standard equation ${ }^{27}$ within the program at $12.0^{\circ} \mathrm{C}$ (table 7 ).

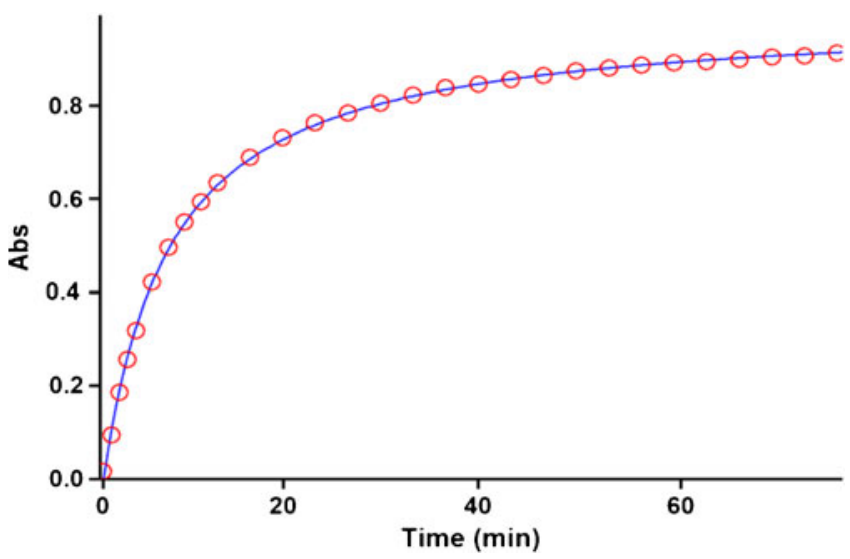

Figure 8. Second order fit curve (full line) accompanied by the original experimental curve (dotted line) for the reaction between compounds $\mathbf{1}, \mathbf{2 c}$ and $\mathbf{3}$ at $330 \mathrm{~nm}$ and $12.0^{\circ} \mathrm{C}$ in 1,2-dichloroethane. 
Table 7. Values of overall second order rate constant for the reaction between $\mathbf{1}, \mathbf{2 c}$ and $\mathbf{3}$ in the presence of solvents such as 1,2-dichloroethane and ethyl acetate, respectively, at all temperatures investigated.

\begin{tabular}{lrrrrr}
\hline & & \multicolumn{4}{c}{$k_{2} \cdot \mathrm{M}^{-1} \cdot \mathrm{min}^{-1}$} \\
\cline { 3 - 6 } Solvent & $\mathcal{E}$ & $12.0^{\circ} \mathrm{C}$ & $17.0^{\circ} \mathrm{C}$ & $22.0^{\circ} \mathrm{C}$ & $27.0^{\circ} \mathrm{C}$ \\
\hline 1,2-Dichloroethane & 10 & 109.1 & 131.5 & 159.6 & 189.2 \\
Ethyl acetate & 6 & 76.1 & 105.3 & 143.2 & 188.6 \\
\hline
\end{tabular}

Furthermore, kinetic studies were carried out using the same concentration of each reactant in the continuation of experiments with concentrations of $5 \times 10^{-3} \mathrm{M}$, and $7 \times 10^{-3} \mathrm{M}$, respectively. As expected, the secondorder rate constant was independent of concentration and its value was the same as in the previous experiment. In addition, the overall order of reaction was also 2 .

\subsection{Effect of solvents and temperature}

To determine the effect of change in temperature and solvent environment on the rate of reaction, it was elected to perform various experiments at different temperatures and solvent polarities but otherwise under the same conditions as for the previous experiment. For this purpose, ethyl acetate with dielectric constant six was chosen as a suitable solvent since it not only could dissolve all compounds but also did not react with them. The effects of solvents and temperature on the rate constant are given in table 7 . The results show that the rate of reaction in each case was increased at higher temperature. In addition, the rate of reaction between $1,2 c$

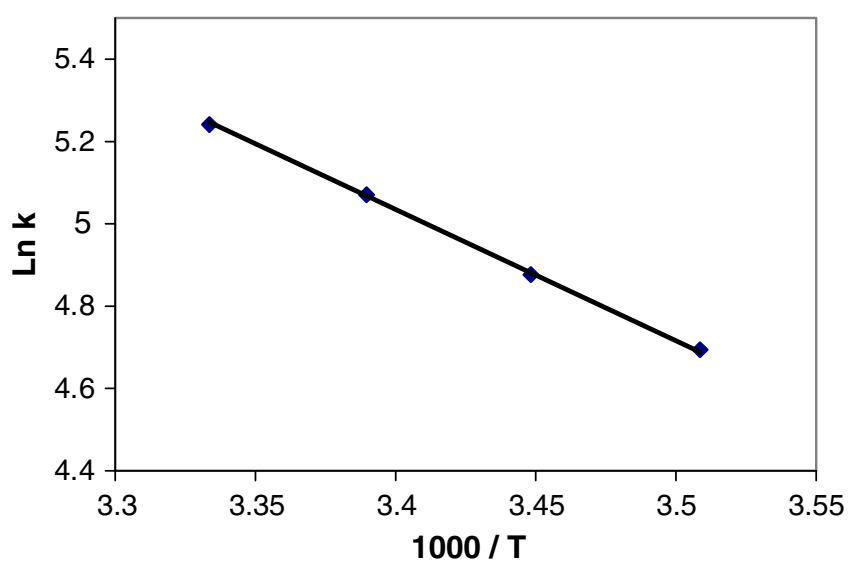

Figure 9. Dependence of second order rate constant (ln $k_{2}$ ) on reciprocal temperature for the reaction between compounds $\mathbf{1}, \mathbf{2 c}$ and $\mathbf{3}$ measured at wavelength $330 \mathrm{~nm}$ in 1 , 2-dichloroethanein accordance with Arrhenius equation. and $\mathbf{3}$ was accelerated in a higher dielectric constant environment (1,2-dichloroethane) in comparison with a lower dielectric constant environment (ethyl acetate) at all temperatures investigated. In the temperature range studied, the dependence of the second-order rate constant $\left(\ln k_{2}\right)$ of the reactions on reciprocal temperature is consistent with the Arrhenius equation, giving activation energy of the reaction between $1,2 \mathrm{c}$ and $\mathbf{3}$ $(26.3 \mathrm{~kJ} / \mathrm{mol})$ from the slope of figure 9 .

\subsection{Effect of concentration}

To determine the reaction order with respect to triphenylphosphine $\mathbf{1}$ and dialkyl acetylene-dicarboxylate 2 (2c), in the continuation of experiments, all kinetic studies were carried out in the presence of excess 3 . Under this condition, the rate equation may therefore be expressed as:

$$
\begin{aligned}
\text { rate } & =k_{o b s}[1]^{\alpha}[2]^{\beta} \quad k_{o b s}=k_{2}[3]^{\gamma} \quad \text { or } \\
\text { Ln } k_{o b s} & =\operatorname{Ln} k_{2}+\gamma \operatorname{Ln}[3] .
\end{aligned}
$$

In this case $\left(3 \times 10^{-2} \mathrm{M}\right.$ of 3 instead of $\left.3 \times 10^{-3} \mathrm{M}\right)$ using the original experimental absorbance versus time data provides a second order fit curve (full line) against time at $330 \mathrm{~nm}$ which exactly fits the experimental curve. The value of rate constant was the same as that of obtained from the previous experiment $\left(3 \times 10^{-3} \mathrm{M}\right)$. Repetition of the experiments with $5 \times 10^{-2} \mathrm{M}$ and $7 \times 10^{-2} \mathrm{M}$ of $\mathbf{3}$ gave, separately, the same fit curve and rate constant. In fact, the experimental data indicated that the observed pseudo second order rate constant $\left(k_{\text {obs }}\right)$ was equal to the second order rate constant $\left(k_{2}\right)$, this is possible when $\gamma$ is zero in equation (1). It appears, therefore, that the reaction is zero and second order with respect to $\mathbf{3}$ (SH-acid) and the sum of $\mathbf{1}$ and 2 (2c) $(\alpha+\beta=2)$, respectively.

To determine the reaction order with respect to dialkyl acetylenedicarboxylate $\mathbf{2}$ (2c), the continuation of experiment was performed in the presence of excess of 1

$$
\text { rate }=k_{\mathrm{obs}}^{\prime}[3]^{\gamma}[2]^{\beta}, \quad k_{\mathrm{obs}}^{\prime}=k_{2}[1]^{\alpha} .
$$

The original experimental absorbance versus time data provides a pseudo first order fit curve at $330 \mathrm{~nm}$, which exactly fits the experimental curve (dotted line) as shown in figure 10.

As a result, since $\gamma=0$ (as determined previously), it is reasonable to accept that the reaction is first order with respect to compound 2 (2c) $(\beta=1)$. Because the overall order of reaction is $2(\alpha+\beta+\gamma=2)$ 


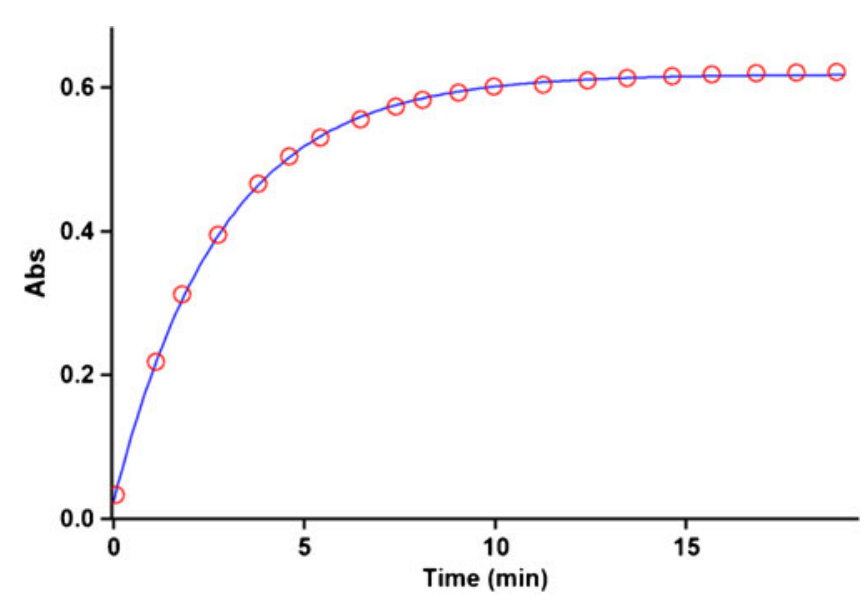

Figure 10. Pseudo first order fit curve (full line) for the reaction between $\mathbf{2 c}$ and $\mathbf{3}$ in the presence of excess $\mathbf{1}$ $\left(10^{-2} \mathrm{M}\right)$ at $330 \mathrm{~nm}$ and $12.0^{\circ} \mathrm{C}$ in 1, 2-dichloroethane.

it is obvious that $\alpha=1$ and order of triphenylphosphine 1 must be equal to one. This result was obtained also for reactions between $(\mathbf{1}, \mathbf{2 b}$ and $\mathbf{3})$ and $(\mathbf{1}, \mathbf{2 a}$ and 3). Based on the above results, a simplified proposed reaction mechanism is shown in figure 11 .

The experimental results indicate that the third step (rate constant $k_{3}$ ) is possibly fast. In contrast, it may be assumed that the third step is the rate determining step for the proposed mechanism. In this case the rate law can be expressed as follows

$$
\text { rate }=k_{3}\left[I_{1}\right][3] .
$$

The steady state assumption can be employed for $\left[\mathrm{I}_{1}\right]$ which is generated following equation,

$$
\left[I_{1}\right]=\frac{k_{2}[1][2]}{k_{-2}+k_{3}[3]} .
$$

The value of $\left[I_{1}\right]$ can be replaced in equation (3) to obtain this equation

$$
\text { rate }=\frac{k_{2} k_{3}[1][2][3]}{k_{-2}+k_{3}[3]} .
$$

Since it was assumed that $k_{3}$ is relevant to the rate determining step, it is reasonable to make the following assumption:

$$
k_{-2} \gg k_{3}[3] .
$$

So the rate of low becomes

$$
\text { rate }=\frac{k_{2} k_{3}[1][2][3]}{k_{-2}} .
$$

The final equation indicates that the overall order of reaction is three which is not compatible with experimental overall order of reaction $(=$ two $)$. In addition, according to this equation, the order of reaction with respect to 3-methoxythiophenol $\mathbf{3}$ is one, whereas it was actually shown to be equal to zero. For this reason, it appeared that the third step is fast. If we assume that the fourth step (rate constant $k_{4}$ ) is the rate-determining step for the proposed mechanism, in this case, there are two ionic species to consider in the rate determining step, namely phosphonium ion

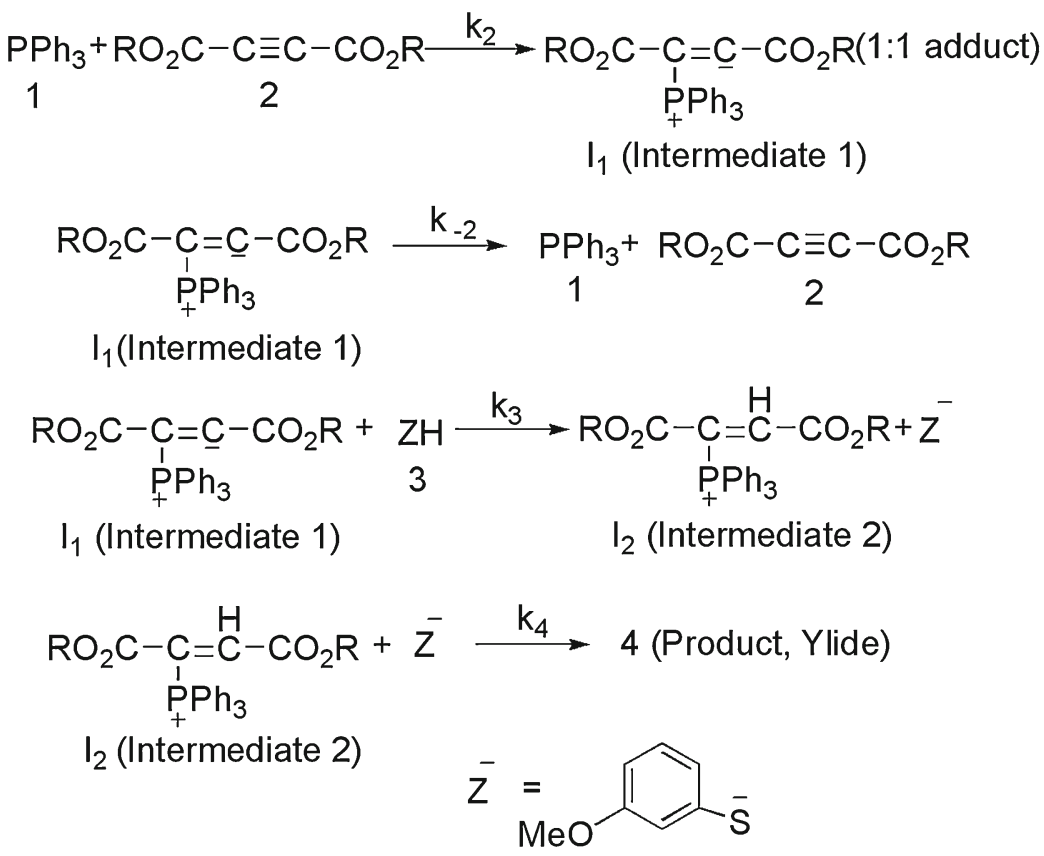

Figure 11. Proposed mechanism for the reaction between $\mathbf{1}, \mathbf{2}(\mathbf{2 a}, \mathbf{2 b}$ or 2c) and $\mathbf{3}$ for generation of phosphorus ylides $\mathbf{4 a - c}$. 
$\left(\mathrm{I}_{2}\right)$ and 3-methoxythiophenol $\left(\mathrm{Z}^{-}\right)$. The phosphonium and 3-methoxythiophenol ions, as we see in figure 11, have full positive and negative charges and form very powerful ion-dipole bonds to the 1,2-dichloroethane, the higher dielectric constant solvent. However, the transition state for the reaction between two ions carries a dispersed charge, which here is divided between the attacking 3-methoxythiophenol and the phosphonium ions. Bonding of solvent (1, 2-dichloroethane) to this dispersed charge would be much weaker than to the concentrated charge of 3-methoxythiophenol and phosphonium ions. The solvent thus stabilizes the species ions more than it would in the transition state, and therefore $E_{a}$ would be higher, slowing down the reaction. However, in practice, 1, 2-dichloroethane speeds up the reaction and for this reason, the fourth step, which is independent of the change in the solvent medium, could not be the rate determining step. Furthermore, the rate law of formation of the product (fourth step) for a proposed reaction mechanism with application of steady state assumption can be expressed by

$$
\text { rate }=k_{4}\left[I_{2}\right]\left[Z^{-}\right] \text {. }
$$

By application of steady state for $\left[\mathrm{I}_{2}\right]$ and $\left[\mathrm{Z}^{-}\right]$, and replacement of their values in the above equation, the following equation is obtained

$$
\text { rate }=\frac{k_{2} k_{3}[1][2][3]}{k_{-2}+k_{3}[3]} .
$$

This equation is independent of rate constant for the fourth step $\left(k_{4}\right)$ and shows why the fourth step would not be affected by a change in the solvent medium. In addition, it has been suggested earlier that the kinetics of ionic species phenomena (e.g., the fourth step) are very fast. ${ }^{28}$ If the first step (rate constant $k_{2}$ ) were the rate determining step, in this case, two reactants (triphenylphosphine $\mathbf{1}$ and dialkyl acetylenedicarboxylate 2), as we see in figure 11, have no charge and could not form strong ion-dipole bonds to the higher dielectric constant solvent, 1, 2-dichloroethane. However, the transition state carries a dispersed charge which here is divided between the attacking $\mathbf{1}$ and $\mathbf{2}$ and, hence, bonding of solvent to this dispersed charge is much stronger than the reactants, which lack charge. The solvent thus stabilizes the transition state more than the reactants and therefore, $E_{a}$ is reduced which speeds up the reaction. Our experimental results show that the solvent with higher dielectric constant exerts a powerful effect on the rate of reaction (in fact, the first step has rate constant $k_{2}$ in the proposed mechanism) but the opposite occurs with the solvent of lower dielectric constant, (see tables 7, 8 and 9). The results of the current work (effects of solvent and concentration of
Table 8. Values of overall second order rate constant for the reaction between $\mathbf{1}, \mathbf{2} \mathbf{b}$ and $\mathbf{3}$ in the presence of solvents such as 1,2-dichloroethane and ethyl acetate, respectively, at all temperatures investigated.

\begin{tabular}{lrrrrr}
\hline & \multicolumn{4}{c}{$k_{2} \cdot \mathrm{M}^{-1} \cdot \mathrm{min}^{-1}$} \\
\cline { 3 - 6 } Solvent & $\mathcal{E}$ & $12.0^{\circ} \mathrm{C}$ & $17.0^{\circ} \mathrm{C}$ & $22.0^{\circ} \mathrm{C}$ & $27.0^{\circ} \mathrm{C}$ \\
\hline 1,2-Dichloroethane & 10 & 631.2 & 677.8 & 753.1 & 878.3 \\
Ethyl acetate & 6 & 411.1 & 532.3 & 615.4 & 696.7 \\
\hline
\end{tabular}

compounds) have provided useful evidence for steps 1 $\left(k_{2}\right), 3\left(k_{3}\right)$ and $4\left(k_{4}\right)$ of the reactions between triphenylphosphine 1, dialkyl acetylenedicarboxylate $\mathbf{2}(\mathbf{2 a}$, $\mathbf{2 b}$ or 2c) and 3-methoxythiophenol 3. Two steps involving 3 and 4 are not rate determining step, although the discussed effects, taken altogether, are compatible with the first step $\left(k_{2}\right)$ of the proposed mechanism and would allow it to be the rate-determining step. However, a good kinetic description of the experimental result using a mechanistic scheme based on the steady state approximation is frequently taken as evidence of its validity. By application of this, the rate formation of product $\mathbf{4}$ from the reaction mechanism (figure 11) is given by:

$$
\frac{d[4]}{d t}=\frac{d[\text { ylide }]}{d t}=\text { rate }=k_{4}\left[I_{2}\right]\left[Z^{-}\right] .
$$

We can apply the steady-state approximation to $\left[\mathrm{I}_{1}\right]$ and $\left[\mathrm{I}_{2}\right]$

$$
\begin{aligned}
& \frac{d\left[I_{1}\right]}{d t}=k_{2}[1][2]-k_{-2}\left[I_{1}\right]-k_{3}\left[I_{1}\right][3], \\
& \frac{d\left[I_{2}\right]}{d t}=k_{3}\left[I_{1}\right][3]-K_{4}\left[I_{2}\right]\left[Z^{-}\right] .
\end{aligned}
$$

To obtain a suitable expression for $\left[\mathrm{I}_{2}\right]$ to put into equation (5) we can assume that, after an initial brief period, the concentration of $\left[\mathrm{I}_{1}\right]$ and $\left[\mathrm{I}_{2}\right]$ achieves a steady state with their rates of formation and rates of disappearance

Table 9. Values of overall second order rate constant for the reaction between $\mathbf{1}, \mathbf{2 a}$ and $\mathbf{3}$ in the presence of solvents such as 1,2-dichloroethane and ethyl acetate, respectively, at all temperatures investigated.

\begin{tabular}{lrrrrr}
\hline & \multicolumn{4}{c}{$k_{2} \cdot \mathrm{M}^{-1} \cdot \mathrm{min}^{-1}$} \\
\cline { 3 - 6 } Solvent & $\varepsilon$ & $12.0^{\circ} \mathrm{C}$ & $17.0^{\circ} \mathrm{C}$ & $22.0^{\circ} \mathrm{C}$ & $27.0^{\circ} \mathrm{C}$ \\
\hline 1,2-Dichloroethane & 10 & 782.3 & 826.2 & 898.1 & 1005.5 \\
Ethyl acetate & 6 & 615.2 & 714.4 & 845.6 & 984.7 \\
\hline
\end{tabular}


just balanced. Therefore $\frac{d\left[I_{1}\right]}{d t}$ and $\frac{d\left[I_{2}\right]}{d t}$ are zero and we can obtain expressions for $\left[\mathrm{I}_{2}\right]$ and $\left[\mathrm{I}_{1}\right]$ as follows

$$
\begin{gathered}
\frac{d\left[I_{2}\right]}{d t}=0, \quad\left[I_{2}\right]=\frac{k_{3}\left[I_{1}\right][3]}{k_{4}\left[Z^{-}\right]} \\
\frac{d\left[I_{1}\right]}{d t}=0, \quad\left[I_{1}\right]=\frac{k_{2}[1][2]}{k_{-2}+k_{3}[3]} .
\end{gathered}
$$

We can now replace $\left[I_{1}\right]$ in the equation (6) to obtain this equation

$$
\left[I_{2}\right]=\frac{k_{2} k_{3}[1][2][3]}{k_{4}\left[Z^{-}\right]\left[k_{-2}+k_{3}[3]\right]} .
$$

The value of $\left[I_{2}\right]$ can be put into equation (5) to obtain the rate equation (8) for proposed mechanism

$$
\begin{aligned}
& \text { rate }=\frac{k_{2} k_{3} k_{4}[1][2][3]\left[S^{-}\right]}{k_{4}\left[Z^{-}\right]\left[k_{-2}+k_{3}[3]\right]} \text { or } \\
& \text { rate }=\frac{k_{2} k_{3}[1][2][3]}{\left[k_{-2}+k_{3}[3]\right]} .
\end{aligned}
$$

Since experimental data were indicated that steps $3\left(k_{3}\right)$ and $4\left(k_{4}\right)$ are fast but step $1\left(k_{2}\right)$ is slow, it is therefore reasonable to make the following assumption:

$$
k_{3}[3] \gg k_{-2} \text {. }
$$

So the rate equation becomes

$$
\text { rate }=k_{2}[1][2] .
$$

This equation which was obtained from a mechanistic scheme (figure 11) by applying the steady-state approxi-

(i)
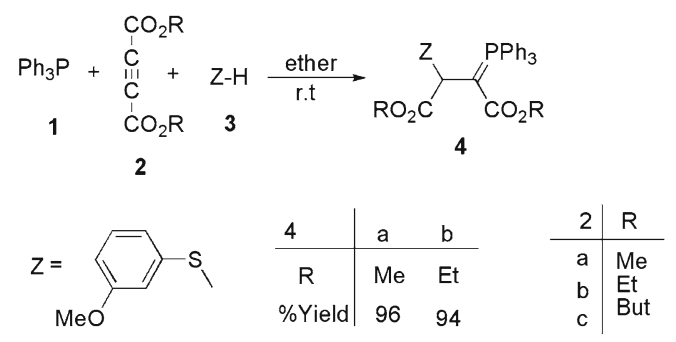

(ii)
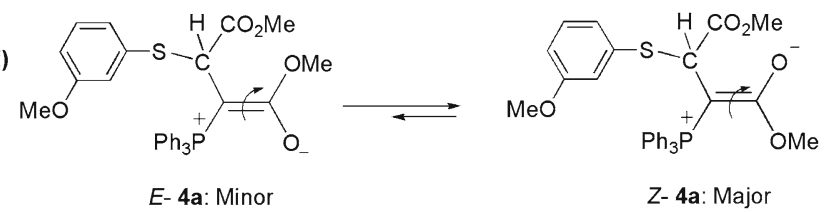

Z- 4a: Major
Figure 12. (i) The reaction between triphenylphosphine 1, dialkyl acetylenedicarboxylate $\mathbf{2}$ (2a or $\mathbf{2 b}$ ) and 3methoxythiophenol $\mathbf{3}$ for generation of stable phosphorus ylides 4 (4a or $\mathbf{4 b}$ ). (ii) The two rotational of isomers $Z-4 \mathbf{a}$ and $E-\mathbf{4 a}$ (minor and major, respectively) for ylide $\mathbf{4 a}$.
Table 10. The activation parameters involving $\Delta \mathrm{G}^{\#}, \Delta \mathrm{S}^{\#}$ and $\Delta \mathrm{H}^{\#}$ for the reactions between $\mathbf{1}, \mathbf{2 a}$ and $\mathbf{3}, \mathbf{1}, \mathbf{2 b}$ and $\mathbf{3}$ and also $\mathbf{1}, \mathbf{2 c}$ and $\mathbf{3}$ at $12.0^{\circ} \mathrm{C}$ in 1, 2-dicholoroethane.

\begin{tabular}{lccc}
\hline Reactions & $\begin{array}{c}\Delta \mathrm{G}^{\#} \\
\left(\mathrm{~kJ} \cdot \mathrm{mol}^{-1}\right)\end{array}$ & $\begin{array}{c}\Delta \mathrm{H}^{\#} \\
\left(\mathrm{~kJ} \cdot \mathrm{mol}^{-1}\right)\end{array}$ & $\begin{array}{c}\Delta \mathrm{S}^{\#} \\
\left(\mathrm{~kJ} . \mathrm{mol}^{-1} \cdot \mathrm{K}^{-1}\right)\end{array}$ \\
\hline $\mathbf{1 , 2 a}$ and 3 & 100.50 & 7.06 & -0.33 \\
$\mathbf{1 , 2 b}$ and 3 & 101.00 & 10.76 & -0.32 \\
$\mathbf{1 , 2 c}$ and 3 & 105.19 & 21.56 & -0.29 \\
\hline
\end{tabular}

mation is compatible with the results obtained by UV spectrophotometry. With respect to the equation (9) that shows the overall reaction rate (figure 12), the activation parameters involving $\Delta \mathrm{G}^{\#}, \Delta \mathrm{S}^{\#}$ and $\Delta \mathrm{H}^{\#}$ could be now calculated for the first step (rate determining step), as an elementary reaction, on the basis of Eyring equation. The results are reported in table 10 .

\subsection{Further kinetic investigations}

3.3a Effect of structure of dialkyl acetylenedicarboxylates: To confirm the above observations, further experiments were performed with diethyl acetylenedicarboxylate $\mathbf{2 b}$ and dimethyl acetylenedicarboxylate 2a, respectively, under the same conditions used in the previous experiments. The values of the secondorder rate constant $\left(k_{2}\right)$ for the reactions between $(\mathbf{1}, \mathbf{2} \mathbf{b}$ and 3$)$ and $(\mathbf{1}, \mathbf{2 a}$ and $\mathbf{3})$ are reported in tables 7 and 8, respectively for all solvents and temperatures investigated. The original experimental absorbance curves (dotted line) accompanied by the second order fit curves (full line), which exactly fit experimental curves (dotted line) confirm the previous observations again for both reactions at $12.0^{\circ} \mathrm{C}$ and $330 \mathrm{~nm}$. As can be seen from tables 7 and 8 the behaviour of diethyl acetylenedicarboxylate $\mathbf{2 b}$ and dimethyl acetylenedicarboxylate $\mathbf{2 a}$ is the same as for the di-tert-butyl acetylenedicarboxylate 2c (table 7) with respect to the reaction with triphenylphosphine 1 and 3-methoxythiophenol 3. The rate of the former reactions was also accelerated in a higher dielectric constant environment and with higher temperatures; however, these rates under the same condition are approximately 7.50 to 6.30 times more than for the reaction with di-tert-butyl acetylenedicarboxylate 2c (see tables 7, 8 and 9). It seems that both inductive and steric factors for the bulky alkyl groups in $\mathbf{2} \mathbf{c}$ tend to reduce the overall reaction rate (see equation 9). In the case of dimetyl acetylenedicarboxylate $\mathbf{2 a}$, the lower steric and inductive effects of the dimethyl groups exert a powerful effect on the rate of reaction. 


\section{Results and discussion}

\subsection{Synthesis}

In the current work, a simple synthesis of stable phosphorus ylids $\mathbf{4}(\mathbf{a}, \mathbf{b})$ was carried out from the reaction between triphenylphosphine $\mathbf{1}$ and dialkyl acetylenedicarboxylates $\mathbf{2}$ in the presence of 3methoxythiophenol $\mathbf{3}$ in fairly high yield (figure 12, i) in ether solvent at room temperature and finished within a few minutes. The ${ }^{1} \mathrm{H}$ and ${ }^{13} \mathrm{C}$ NMR spectra of the crude product clearly indicated the formation of compounds $\mathbf{4 a - b}$. No products other than $\mathbf{4 a - b}$ could not be detected by NMR spectroscopy. The structures of compounds $\mathbf{4 a}-\mathbf{b}$ were deduced from their IR, ${ }^{1} \mathrm{H},{ }^{13} \mathrm{C}$ and ${ }^{31} \mathrm{P}$ NMR spectra. Although the presence of the ${ }^{31} \mathrm{P}$ nucleus complicates both the ${ }^{1} \mathrm{H}$ and ${ }^{13} \mathrm{C}$ NMR spectra of $\mathbf{4 a}$, it helps in assignment of the signals by longrange couplings with the ${ }^{1} \mathrm{H}$ and ${ }^{13} \mathrm{C}$ nuclei (see experimental section). The ${ }^{1} \mathrm{H},{ }^{13} \mathrm{C}$, and ${ }^{31} \mathrm{P}$ NMR spectra of ylides $\mathbf{4} \mathbf{a}-\mathbf{b}$ are compatible with the presence of two geometrical isomers. The ylides moiety of these compounds are strongly conjugated with the adjacent carbonyl group and rotation around the partial double bond in $(E)-\mathbf{4}$ and $(Z)-\mathbf{4}$ geometrical isomers is slow on the NMR time-scale at ambient temperature (figure 12, ii).

On the basis of the well-established chemistry of trivalent phosphorus nucleophiles, ${ }^{3-7}$ it is reasonable to assume that phosphorus ylide 4 results from the initial addition of triphenylphosphine to the acetylenic esters and subsequent protonation of the 1:1 adduct by the 3-methoxythiophenol to form phosphoranes 4 . The ${ }^{1} \mathrm{H}$ NMR spectrum of $\mathbf{4 a}$ showed three sharp lines at $\delta=3.11,3.58$ and $3.66 \mathrm{ppm}$ arising from methoxy protons. Methine protons appeared as the two doublet peaks at $\delta=4.12 \mathrm{ppm}\left(1 \mathrm{H}, \mathrm{d},{ }^{3} J_{\mathrm{PH}}=19.0 \mathrm{~Hz}, \mathrm{P}-\right.$ $\mathrm{C}-\mathrm{C} H)$ and $4.27\left(1 \mathrm{H}, \mathrm{d},{ }^{3} J_{\mathrm{PH}}=18.3 \mathrm{~Hz}, \mathrm{P}-\mathrm{C}-\mathrm{C} H\right)$, respectively, for the major and minor geometrical isomer. The aromatic protons appeared as a multiplet at $\delta=6.55-7.67 \mathrm{ppm}$. The ${ }^{13} \mathrm{C}$ NMR spectrum of $\mathbf{4 a}$ displayed 17 distinct resonances in a good agreement with only one isomer. The ${ }^{1} \mathrm{H}$ and ${ }^{13} \mathrm{C}$ NMR spectra of compound $\mathbf{4 b}$ is similar to that of $\mathbf{4 a}$, except for the signals from the ester group, which appear as characteristic resonance lines with the corresponding chemical shifts. The structural assignments for compounds $\mathbf{4 a - b}$ were made on the basis of the ${ }^{1} \mathrm{H}$ and ${ }^{13} \mathrm{C}$ NMR spectra that were supported by their IR spectra. The carbonyl region of the spectra exhibits two distinct IR absorption bands for each compound. Of special interest is the ester absorption at $1730-1630 \mathrm{Cm}^{-1}$. Conjugation of negative charge in ylide region with the carbonyl of ester group within the structure of ylide accounts for the reduction of the wave numbers of the carbonyl absorption bands $\mathrm{Ph}_{3} \mathrm{P}^{+}-\mathrm{C}=\mathrm{C}-\mathrm{O}^{-}$.

\section{Conclusion}

In conclusion, we have prepared novel phosphorus ylides $\mathbf{4 a}-\mathbf{b}$ using a one-pot reaction between triphenylphosphine and dialkyl acetylenedicarboxylates in the presence of 3-methoxythiophenol. The present method, carries the advantage that, not only the reaction is performed under neutral conditions, but also the substances can be mixed without any activation or modifications. Compounds containing phosphorus ylides $\mathbf{4 a - b}$ may be considered as potentially useful synthetic intermediates. It seems that, the procedure described here may be employed as an acceptable method for the preparation of phosphoranes with variable functionalities. The assignment of the $Z$ - and $E$-isomer as a minor or major form in both the ylides 4a and 4b were undertaken by AIM and NPA methods and also CHelpG keyword. Quantum mechanical calculations clarified how the ylides $\mathbf{4 a}$ and $\mathbf{4 b}$ exist in solution as a mixture of the two geometrical isomers. This result was slightly different from the experimental data due to the different media used for experimental measurement and theoretical calculations. In addition, kinetic investigation of these reactions was undertaken using UV spectrophotometry. The results can be summarized as given below. (i) The appropriate wavelengths and concentrations were determined to follow the reaction kinetics. (ii) The overall reaction order followed second-order kinetics and the reaction orders with respect to triphenylphosphine, dialkyl acetylenedicarboxylate and 3-methoxythiophenol were one, one and zero, respectively. (iii) The values of the secondorder rate constants of all reactions were calculated automatically with respect to the standard equation, using the software associated with the Cary-300 UV equipment. (iv) The rates of all reactions were accelerated at higher temperatures. Under the same conditions, the activation energy for the reaction with di-tert-butyl acetylenedicarboxylate $2 \mathrm{c}(26.3 \mathrm{~kJ} / \mathrm{mol})$ was higher than that for the both reactions which were followed by the diethyl acetylenedicarboxylate $\mathbf{2 b}$ $(15.5 \mathrm{~kJ} / \mathrm{mol})$ and dimethyl acetylenedicarboxylate $\mathbf{2 a}$ $(11.8 \mathrm{~kJ} / \mathrm{mol})$ in 1,2-dichloroethane. (v) The rates of all reactions were increased in solvents of higher dielectric constant and this can be related to differences in stabilization by the solvent of the reactants and the activated complex in the transition state. (vi) Increased steric bulk in the alkyl groups of the dialkyl acetylenedicarboxylates, accompanied by the correspondingly greater inductive effect, reduced the overall reaction rate. 
(vii) With respect to the experimental data, the first step of the proposed mechanism was recognized as a rate-determining step $\left(k_{2}\right)$ and this was confirmed based on the steady-state approximation. (viii) Also, the third step was identified as a fast step $\left(k_{3}\right)$. (ix) The activation parameters involving $\Delta \mathrm{G}^{\#}, \Delta \mathrm{S}^{\#}$ and $\Delta \mathrm{H}^{\#}$ were reported for three reactions.

\section{Acknowledgements}

Authors sincerely thank the University of Sistan \& Baluchestan, Payam Noor University and Islamic Azad University of Kerman for providing the financial support of this work.

\section{References}

1. Nakamura M, Miki M and Majima T 2008 J. Chem. Soc. Perkin Trans. 21447

2. Yasui S, Tojo S and Majima T 2005 J. Org. Chem. 701276

3. Engel R and Cohen J L 2004 Synthesis of carbonphosphorus bond (Boca Raton: CRC Press)

4. Engel R 2004 Synthesis of carbon-phosphorus bonds (Boca Raton: CRC Press)

5. Allen D W and Tebby J C 2000 Organophosphorus chemistry (Cambridge: Royal Society of Chemistry)

6. Hartley F R 1994 The chemistry of organophosphorus compounds (New York: Wiley)

7. Hudson H R 1990 Primary, secondary and tertiary phosphines, polyphosphines and heterocyclic organophosphorus (III) compounds, in the chemistry of organophosphorus compounds (ed) F R Hartley (New York: Wiley)

8. Hassanabadi A, Anary-Abbasinejad M and Dehghan A 2009 Synth. Commun. 39132

9. Ramazani A, Kazemizadeh A R, Ahmadi E, Noshiranzadeh N and Souldozi A 2001 Curr. Org. Chem. 1259
10. Lu X, Zhang C and Xu Z 2001 Acc. Chem. Res. 34 535

11. Anaraki-Ardakani H, Sadeghian S, Rastegari F, Hassanabadi A and Anary-Abbasinejad M 2008 Synth. Coтmun. 381990

12. Islami M R, Mollazehi F, Badiei A and Sheibani H 2005 Arkivoc (xv) 25

13. Esmaili A A, Ghereghloo M, Islami M R and Bijanzadeh H R 2003 Tetrahedron 594785

14. Maghsoodlou M T, Hazeri N, Habibi-Khorassani S M, Ghulame-Shahzadeh A and Nassiri M 2006 Phosphorus Sulfur Silicon Relat. Elem. 181913

15. Yavari I and Alizadeh A A 2003 Monatsh Chem. 134 435

16. Bhuvan Kumar N N, Chakravarty $\mathrm{M}$ and Kumara Swamy K C 2006 New J. Chem. 301614

17. Maghsoodlou M T, Hazeri N, Habibi-Khorassani S M, Moeeni Z, Marandi G h, Lashkari M, Ghasemzadeh M and Bijanzadeh H R 2007 J. Chem. Res. 10566

18. Wang Z G, Zhang G T, Guzei I and Verkade J G 2001 J. Org. Chem. 103521

19. Maghsoodlou M T, Habibi-Khorassani S M, Rofouei M K, Adhamdoust S R and Nassiri M 2006 Arkivoc (xii) 145

20. Reed A E, Weinstock R B and Weinhold F J $1985 J$. Chem. Phys. 83735

21. Frisch M J et al. 1998 Gaussian 98, Revision A. 7, Gaussian, Inc., Pittsburgh, PA

22. Bader R F W 1990 Atoms in molecules a quantum theory (New York: Oxford University)

23. Biegler König F W, Schönbohm J and Bayles D J 2001 Comput. Chem. 22545

24. Grabowski S J 2001 J. Mol. Struct. 562137

25. Arnold W D and Oldfield E 2000 J. Am. Chem. Soc. 122 12835

26. Rozas I, Alkorta I and Elguero J $2000 \mathrm{~J}$. Am. Chem. Soc. 12211154

27. Schwartz L M and Gelb R I 1978 Anal. Chem. 50 1592

28. Okubo T, Maeda Y and Kitano H 1989 J. Phys. Chem. 933721 